JURNAL KETAHANAN NASIONAL

Vol. 24, No.2, Agustus 2018, Hal 152-169

DOI:http://dx.doi.org/ 10.22146/jkn.35318

ISSN:0853-9340(Print), ISSN:2527-9688(Online)

Online sejak 28 Desember 2015 di :http://jurnal.ugm.ac.id/JKN

VOLUME 24

No. 2, Agustus 2018

Halaman 152-169

\title{
Pengaruh Praktik Belajar Kewarganegaraan Berbasis Media Massa Terhadap Keterampilan Berpikir Kritis dan Implikasinya Terhadap Ketahanan Pribadi Siswa
}

\author{
Dian Eka Putri \\ Program Pascasarjana Universitas Negeri Yogyakarta, Indonesia \\ Email: dianeka1420@gmail.com \\ Mukhamad Murdiono \\ Universitas Negeri Yogyakarta, Indonesia \\ Email: mukhamad_murdiono@uny.ac.id
}

\begin{abstract}
This study was aimed at determining the influence of project citizen based on mass media on student's critical thinking skills, and the implication towards student's personal resilience in second grade of Senior High School 4 Surakarta, Central Java.

This research was a quasi experimental study with pretest-posttest control group design. This research was conducted in class XI semester 2 at Senior High School 4 Surakarta, Central Java in the academic year 2017/2018. The research population was all of second grade student's in Senior High School 4 Surakarta, Central Java. Sampling was taken by simple random sampling technique. This study used one experiment group and one control group. Data collection was done through pretest, posttest, questionaire, and observation. The research instruments in this research were test and non test instruments. The data analysis technique used multivariate analysis of variance manova test using SPSS 22.0.

The result of this research showed that there was significant influence of project citizen model based on mass media on student's critical thinking skills with significance of $0.033 \leq 0.05$. The equal 0.033 with positive signs indicated the positive direction (accordance), meaning that the better implementation of project citizen model based on mass media, the better also student's critical thinking skills. Critical thinking skills that showed a positive direction had implications towards student's personal resilience. The critical thinking skills that students possess were essentially clear or logical thinking and actually look deeply at relevant concepts by exploring things like the fundamental problem. In the process of critical thinking, all things were considered to be contemplated, thought out, and then concluded logically and clearly. It was a high-level thinking skill that became student's personal resilience as a young citizen in order to analyzed problem solving.
\end{abstract}

Keyword: Project Citizen, Mass Media, Critical Thinking Skill, Personal Resilience

\begin{abstract}
ABSTRAK
Penelitian ini bertujuan untuk mengetahui pengaruh praktik belajar kewarganegaraan berbasis media massa terhadap keterampilan berpikir kritis dan implikasinya terhadap ketahanan pribadi siswa kelas XI di SMA Negeri 4 Surakarta, Jawa Tengah.

Penelitian ini merupakan penelitian quasi experimental (eksperimen semu) dengan desain penelitian pretestposttest. Penelitian ini dilakukan pada kelas XI semester 2 di SMA Negeri 4 Surakarta, Jawa Tengah tahun ajaran 2017/2018. Populasi penelitian yaitu siswa kelas XI di SMA N 4 Surakarta, Jawa Tengah. Teknik pemilihan sampel yaitu teknik simple random sampling. Penelitian ini dilakukan pada satu kelompok eksperimen dan satu kelompok
\end{abstract}


kontrol. Data dikumpulkan dengan cara pretest, posttest, kuesioner, dan observasi. Instrumen penelitian yang digunakan dalam penelitian ini adalah instrumen tes dan non tes. Teknik analisis data menggunakan uji analisis multivariat varian menggunakan program SPSS 22.0.

Hasil penelitian menunjukkan adanya pengaruh yang signifikan positif dari model praktik belajar kewarganegaraan berbasis media massa terhadap keterampilan berpikir kritis siswa dengan signifikansi sebesar 0,033 $\leq 0,05$. Angka 0,033 bertanda positif menunjukkan arah positif (searah), artinya bahwa semakin baik penerapan praktik belajar kewarganegaraan berbasis media massa maka semakin baik pula keterampilan berpikir kritis siswa. Keterampilan berpikir kritis yang menunjukkan arah positif(searah) berimplikasi terhadap ketahanan pribadi siswa. Keterampilan berpikir kritis yang dimiliki siswa merupakan pemikiran secara jelas atau logis dan benar-benar melihat secara mendalam terhadap berbagai konsep yang relevan dengan mengeksplorasi hal-hal seperti masalah yang mendasar. Dalam proses berpikir kritis, semua hal dipertimbangkan untuk direnungkan, dipikirkan, kemudian disimpulkan secara logis dan jelas. Hal ini merupakan keterampilan berpikir tingkat tinggi yang menjadi ketahanan pribadi siswa dalam rangka analisis penyelesaian masalah.

Kata Kunci: Praktik Belajar Kewarganegaraan, Media Massa, Keterampilan Berpikir Kritis, Ketahanan Pribadi

\section{PENGANTAR}

Dunia pendidikan terus mengalami periode tantangan yang terus berkembang di setiap era. Terjadi berbagai macam permasalahan yang menguji eksistensi dunia pendidikan Indonesia. Pelaksanaan sistem pendidikan nasional nampaknya tidak konsisten antara das sollen dan das sein, bahkan realitasnya nampak tidak memiliki visi filosofis yang jelas (Kaelan, 2012: 66). Pasal 1 UU Nomor 20 Tahun 2003 tentang Sistem Pendidikan Nasional, memaparkan bahwa "pendidikan nasional merupakan pendidikan yang berdasarkan Pancasila dan UndangUndang Dasar Tahun 1945, yang berakar pada nilai-nilai agama, kebudayaan nasional Indonesia dan tanggap terhadap tuntutan perubahan zaman". Namun kenyataannya, permasalahan dalam bidang pendidikan di Indonesia terus muncul bahkan semakin kompleks.

Pembahasan permasalahan dunia pendidikan, mengarahkan suatu kajian pendidikan di sekolah. Hal ini dikarenakan sekolah merupakan komponen utama pendidikan perlu memperhatikan kegiatan pembelajaran yang berlangsung, apakah sesuai atau tidak dengan tujuan pembelajaran yang hendak dicapai. Tejadi banyak permasalahan dalam proses pendidikan bangsa Indonesia, terutama pada mentalitas siswa yang semakin hari dinilai semakin kurang mencerminkan mentalitas seorang generasi penerus bangsa. Permasalahan-permasalahan moral dan daya kritis siswa terus meningkat dalam pengertian yang negatif. Fajar (2005:15) menilai bahwa permasalahan ini memiliki penyebab yang sistematis seperti misalnya ada permasalahan dalam proses pembelajaran yang berpusat pada siswa, harus ada pengembangan kreativitas, harus tercipta kondisi yang menyenangkan, harus lebih ditekankan nilai dan etika siswa, serta harus tersedianya proses pengalaman belajar yang beragam.

Persoalan nilai, norma, etika, dan sikap kritis siswa pada dasarnya menjadi kewajiban semua subjek mata pelajaran sekolah, akan tetapi kajian-kajian ini sangat dekat dengan kajian subjek pendidikan kewarganegaraan. Pendidikan kewarganegaraan itu sendiri merupakan suatu pendidikan yang mengkaji tentang orientasi sikap dan perilaku warga negara dalam proses politik berwarga negara antara warga negara dengan negara. Sikap warga negara yang dimaksud di sini ialah sikap warga negara terkait dengan nilai, norma, dan etika yang dianut sampai dengan jiwa kritis warga negara dalam menjalankan hak dan 
kewajibannya (Hamidi dan Lutfi, 2010:77). Terkait dengan fenomena tersebut, di abad ke-21 ini, seharusnya seorang warga negara setidaknya memiliki delapan kemampuan atau karakter manusia modern di abad 21, yaitu kemampuan untuk mengenal masalah global, kemampuan untuk bekerjasama dengan orang lain, kemampuan untuk toleran, kemampuan untuk berpikir kritis, kemampuan untuk menyelesaikan masalah, kemampuan untuk mengubah gaya hidup, kemampuan untuk peka terhadap perkara hak asasi manusia, dan kemampuan untuk berpartisipasi pada proses politik (Cogan dan Derricott, 1998:116).

Terkait dengan permasalahan nilai, norma, etika, sikap dan pemikiran kritis siswa, fenomena proses pendidikan yang terjadi di Indonesia, terutama terkait dengan subjek mata pelajaran pendidikan kewarganegaraan memperlihatkan suatu fenomena yang kurang positif dikarenakan masih terjadi berbagai masalah dalam proses pendidikan dan pembelajarannya. Hal ini berdasarkan data hasil penelitian yang dilakukan oleh Kerr (1999:5-7) yang memaparkan tentang proses pendidikan kewarganegaraan di Asia, termasuk di dalamnya adalah Indonesia, pendidikan kewarganegaraan hanya berjalan formal dan masuk dalam kategori yang minimal karena hanya terikat oleh isi dan hanya berorientasi pada aspek kognitif saja. Hal tersebut sejalan dengan pendapat Winataputra dan Budimansyah (2012:1416) yang mengemukakan tentang landasan dikembangkannya civic education, yang terangkum dalam beberapa poin alasan, yaitu (1). Alokasi waktu dalam kurikulum yang terkesan kaku dan ketat sehingga guru memiliki keterbatasan untuk berimprovisasi dalam proses pembelajaran; (2). Pelaksanaan pembelajaran yang mengarah pada dominasi aspek kognitif saja sehingga aspek yang lain menjadi tidak seimbang; dan (3). Pembelajaran yang hanya berorientasi pada aspek kognitif membuat guru harus selalu mengejar target pencapaian materi saja, dan mengesampingkan aspek yang sikap dan keterampilan.

Proses pembelajaran PPKn pada umumnya masih berlangsung secara konvensional dengan mengandalkan metode ceramah dan hafalan tanpa adanya suatu variasi. Pembelajaran yang mengutamakan ceramah dan hafalan cenderung kurang menarik dan membuat siswa cepat merasa bosan. Selama ini siswa beranggapan pelajaran PPKn itu tidak menarik dan membosankan. Kesan ini muncul karena secara substansif pelajaran PPKn kurang menyentuh kebutuhan siswa. Guru kurang memunculkan permasalahan aktual yang dihadapi siswa sebagai masyarakat muda dan mengarahkan siswa untuk bisa mengembangkan kemampuan berpikirnya agar bisa mengatasi berbagai permasalahan tersebut. Padahal jika dicermati lebih dalam, Pendidikan Kewarganegaraan memperlajari tentang kehidupan masyarakat dengan berbagai dinamikanya yang seharusnya menarik untuk dipelajari bersama

Wahab dan Sapriya (2008:3) juga memaparkan tentang alasan permasalahan yang terjadi dalam pendidikan kewarganegaraan, yaitu adanya proses pembelajaran yang terkesan monoton atau itu-itu saja, padahal dalam proses pembelajaran mata pelajaran seperti PKn, seharusnya terdapat dinamika pembelajaran yang menarik minat siswa, hal ini karena kajian utamanya ialah isu-isu yang berkembang pada warga negara atau masyarakat. Adapun dinamika permasalahan yang muncul dalam pembelajaran Pendidikan Pancasila dan Kewarganegaraan pada dasarnya tidak lepas dari kurangnya kepekaan pendidik 
Gambar 1

Penetrasi Pengguna Internet di Indonesia

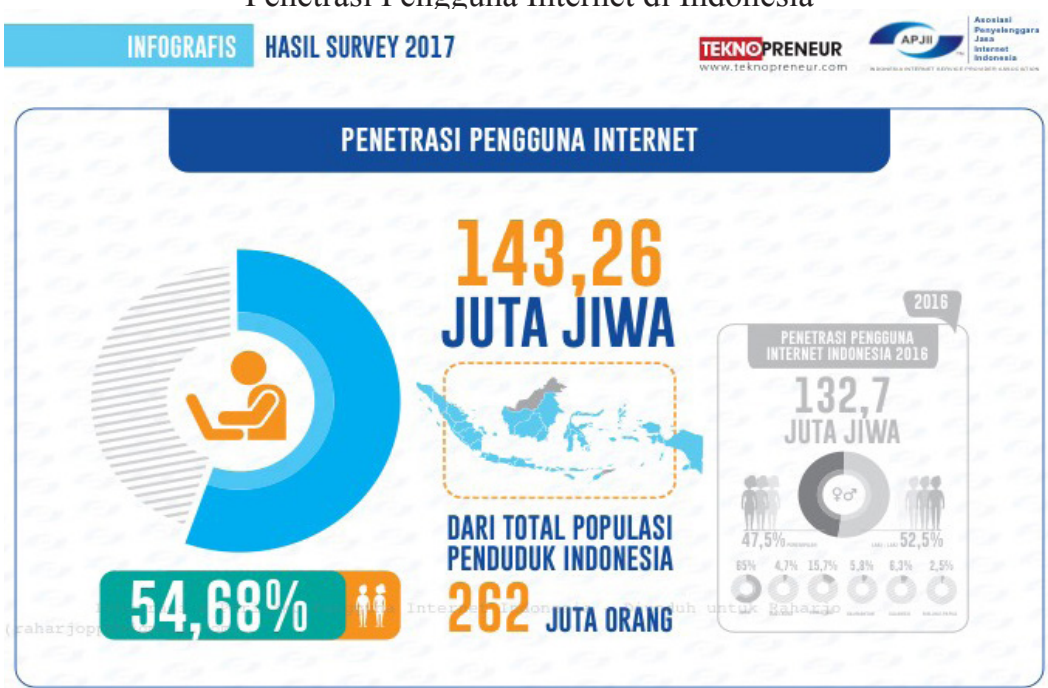

Sumber: Asosiasi Penyelenggara Jasa Internet Indonesia (2017:6)

atau guru dalam merespons perkembangan dunia pendidikan di era globalisasi saat ini. Pada dasarnya, sudah menjadi tugas guru untuk merespons perkembangan dunia pendidikan kontemporer. Pemanfaatan berbagai macam model dan media pembelajaran harus terus dikembangkan. Adapun salah satu hal penting dalam dunia digital saat ini ialah informasi. Informasi pada prinsipnya disampaikan kepada masyarakat melalui media. Proses penyampaian informasi ini, kemudian dapat berlangsung cepat dalam penyebarannya di masyarakat. Dekatnya generasi saat ini dengan gadget memudahkan masyarakat untuk mengakses informasi. Fenomena ini dapat dijadikan sebagai alternatif solusi dari permasalahan proses kegiatan belajar mengajar, yaitu pemanfaatan media massa dalam proses kegiatan belajar mengajar. Media massa menjadi media penyampaian informasi yang berpengaruh bagi masyarakat.

Dinamika penyebaran informasi yang berkembang pesat, merupakan akibat dari perkembanagn IPTEK, terutama perkembangan teknologi internet pada era digital ini. Masyarakat semakin melek teknologi karena adanya akses internet yang dilakukan masyarakat sebagai bentuk gaya hidup masyarakat modern. Penggunaan internet pada dasarnya merambah ke segala lapisan masyarakat, digunakan untuk pekerjaan, belajar, dan lain sebagainya. Survei yang dilakukan oleh APJII (2017) tentang Data Statistik Pengguna Internet Indonesia menunjukkan data penetrasi pengguna internet yang meningkat secara signifikan sebagai berikut.

Gambar 1 tersebut memaparkan tentang penetrasi pengguna internet di Indonesia, diketahui hasil survei menunjukkan bahwa di Indonesia terdapat 54,68\% (lima puluh empat koma enam puluh delapan persen) dari total penduduk sebesar 262 juta jiwa atau 143,26 juta user. Lima puluh delapan koma nol delapan persen $(58,08 \%)$ pengguna berasal dari Pulau Jawa yang menjadi mayoritas pengguna internet. Jika dibandingkan dengan tahun 2014 pengguna internet Indonesia yaitu sebesar 88,1 juta user, maka di tahun 2017 terjadi kenaikkan sebesar 55,16 juta (Lima 
puluh lima koma enambelas juta) (dalam waktu 3 tahun 2014-2017) (APJII, 2017:6-7). Adapun menurut konten yang diakses, sebesar 87,13\% (Delapan puluh tuju koma tigabelas persen) pengguna internet di Indonesia mengakses media sosial, 74,84\% (Tujuh puluh empat koma delapan puluh empat persen) mengakses konten melalui search engine, 72,79\% (Tujuh puluh dua koma tujuh puluh sembilan persen) mengakses konten gambar/ foto, 69,84\% (Enam puluh Sembilan koma delapan puluh empat persen) mengakses konten video, 55,30\% (Lima puluh lima koma tiga puluh persen) mengakses konten artikel, 35,89\% (Tiga puluh lima koma delapan puluh sembilan persen) pengguna melakukan upload file, 33,58\% (Tiga puluh tiga koma lima puluh delapan persen) mengakses email, 32,19\% (Tigapuluh dua koma Sembilanbelas persen) pengguna melakukan akses transaksi beli barang, 16,97\% (Enam belas koma sembilan puluh tujuh persen) melakukan registrasi atau pendaftaran dan 8,12\% (Delapan koma duabelas persen)pengguna memanfaatkan internet untuk jual barang (APJII, 2017:28).

Adanya peningkatan penetrasi pemakaian internet di Indonesia menjadi salah satu sarana media massa yang memberikan berbagai macam informasi baik yang sifatnya privat maupun publik. Media massa yang berbasis internet, pada saat ini berkembang pesat dan sangat masif dalam menyebarkan informasi atau pemberitaan. Pengembangan media massa berbasis internet tersebut dibuktikan dengan data perilaku masyarakat terkait penggunaan internet menurut konten yang diakses yaitu $87,13 \%$ (Delapan puluh tuju koma tiga belas persen) pengguna internet di Indonesia mengakses media sosial, 74,84\% (Tujuh puluh empat koma delapan puluh empat persen) mengakses konten berita melalui search engine, dan 55,30\% (Lima puluh lima koma tiga puluh persen) mengakses konten artikel. Hal ini menunjukkan adanya potensi untuk melakukan pemanfaatan fenomena perkembangan teknologi informasi dalam pelaksanaan model dan media pembelajaran. Hal tersebut didukung oleh penelitian Ferry (2014:42) yang mengkaji tentang peran media massa dan pengaruhnya bagi remaja, yang pada intinya dijelaskan bahwa media massa merupakan media yang berpengaruh terhadap masuknya informasi-informasi bagi remaja, baik informasi yang sifatnya formal atau berita maupun informasi-informasi yang sifatnya non formal atau hiburan. Hasil penelitian tersebut, mengindikasikan bahwa media massa memiliki peran penting dalam proses penyampaian informasi di era saat ini. Hal ini menunjukkan bahwa media massa memiliki potensi yang positif jika dimanfaatkan untuk pembelajaran. Kompetensi pedagogis dan profesional guru harus ditunjang dengan berbagai macam inovasi pembelajaran yang sesuai dengan tujuan pembelajaran, lebih spesifik lagi, sesuai dengan proses pembelajaran Pendidikan Pancasila dan Kewarganegaraan.

Dewasa ini, diketahui bersama bahwa informasi ataupun pemberitaan yang beredar di masyarakat, terkesan semakin dinamis dan masif. Adapun dampak positif dan negatif dapat dirasakan dengan adanya kemudahan penyampaian informasi terkini melalui media massa. Di samping masyarakat semakin up to date dengan segala macam informasi terkini, permasalahan yang ditimbulkan oleh media massa juga termasuk hal-hal yang negatif, misalnya yaitu kasus penyebaran hoax atau berita tidak benar, kemudian penyebaran kebencian atau hate speech. Adapun media massa merupakan segala macam media penyampaian 
informasi kepada masyarakat, termasuk media sosial yang saat ini sudah menjadi media masyarakat dalam berkomunikasi sehari-hari. Adapun pembelajaran Pendidikan Pancasila dan Kewarganegaraan pada dasarnya sangat erat kaitannya dengan kehidupan masyarakat, sehingga pemanfaatan media massa untuk dunia pendidikan dan pembelajaran dapat dimanfaatkan sebagai media pembelajaran di kelas.

Selanjutnya, terkait dengan kondisi lapangan tempat penelitian, berangkat dari kajian latar belakang yang disusun, data pra penelitian di beberapa kelas XI SMA Negeri 4 memperlihatkan adanya proses pembelajaran yang standar tanpa adanya pengembangan model maupun media pembelajaran tertentu. Siswa terlihat hanya mendengarkan, membaca buku pegangan, kemudian di akhir pembelajaran ada diskusi, dipersilahkan untuk siswa apabila ada yang ingin bertanya, akan tetapi mayoritas kelas yang peneliti observasi, tidak ada pertanyaan yang diajukan oleh siswa, hanya ada satu atau dua siswa yang bertanya, meminta ulang penjelasan materi yang baru saja dijelaskan oleh guru. Kondisi ini menunjukkan adanya proses pembelajaran yang monoton atau biasa-biasa saja. Siswa kurang tertarik dengan proses pembelajaran Pendidikan Pancasila dan Kewarganegaraan. Siswa terlihat tidak aktif dalam berpikir kritis dan enggan untuk menyampaikan pertanyaan atau pendapat dan tanggapan dari pembahasan materi pembelajaran. Dengan demikian, hasil observasi pra penelitian menunjukkan bahwa guru masih cenderung dominan memakai model pembelajaran konvensional. Namun begitu, penggunaan model konvensional oleh guru bukan tanpa alasan, alasan utama dari guru ialah dalam penggunaan model pembelajaran harus ada persiapan yang cukup dan matang, selain jam mengajar yang banyak, guru juga mengalami kesulitan dalam penguasaan materi PPKn yang menurut guru terlalu banyak, ditambah ada juga tugas-tugas lain di sekolah yang harus diselesaikan oleh guru.

Berdasar pada permasalahan yang peneliti kaji dan permasalahan yang terjadi di lapangan, ada berbagai alternatif model pembelajaran dalam rangka untuk menyelesaikan permasalahan yang dihadapi, salah satunya ialah praktik belajar yang merupakan pengembangan dari model pendekatan berpikir kritis atau reflektif yang pada mulanya dirintis oleh John Dewey (1900) dengan paradigma how we think atau model reflective inquiry yang dikemukakan oleh Barr (1978) (Budimansyah, 2009:10).

Beberapa penelitian terkait dengan kajian praktik belajar kewarganegaraan, Jayadiputra (2015:18) memaparkan bahwa praktik belajar kewarganegaraan secara signifikan dapat meningkatkan kemampuan berpikir kritis dalam proses pembelajaran yang dilakukan oleh siswa. Dalam proses pembelajaran, siswa diharuskan peka terhadap permasalahan atau isu yang terjadi di lingkungan sekitar. Selain itu, siswa juga dituntut untuk memberikan solusi untuk masalah yang ditemukan. Kemudian, penelitian yang dilakukan oleh Nusarastriya, Sapriya, Wahab, dan Budimansyah (2013:444) menegaskan bahwa pengembangan berpikir kritis menggunakan praktik belajar kewarganegaraan yang didahului dengan pemahaman tentang berpikir kritis pada akhirnya memperoleh hasil yang lebih maksimal dari pada yang tidak menggunakan praktik belajar kewarganegaraan. Selanjutnya, penelitian yang dilakukan oleh Raharjo, Armawi dan Soerjo (2017) memaparkan bahwa ada implikasi terhadap ketahanan pribadi dalam rangka proses sosialisasi civic 
literacy yang merupakan bagian dari kajian Pendidikan Kewarganegaraan. Penelitian tersebut menjelaskan bahwa penguatan civic literacy berimplikasi pada ketahanan pribadi pemuda, yaitu berupa pola pikir dan pola perilaku yangmenunjukkan adanya keinginan pemuda untuk terus berusaha mempraktikkan materi-materi civic literacy yang mereka sampaikan saat sosialisasi pada kehidupan sehari-hari. Adapun pola pikir dan pola perilaku dalam kajian ini erat kaitannya dengan kajian keterampilan berpikir kritis. Kemudian, terkait dengan penggunaan media massa dalam praktik belajar kewarganegaraan, Suwignyo dan Yuliantri (2018) memaparkan hubungan tentang praktik kewargaan dan media massa yaitu melalui penelitian dengan metode sejarah untuk membaca berbagai berita surat kabar tahun 1950an sebagai sumber data primer disimpulkan bahwa praktik kewargaan yang dilakukan sehari-hari yaitu dalam bentuk beberapa program seperti filantropis, aksi gerakan dan perkumpulan sosial yang menjadi suatu tanda ketahanan kolektif masyarakat dalam menghadapi keadaan tak menentu yang terjadi saat itu. Meskipun demikian, dijelaskan oleh peneliti bahwa praktik kewargaan yang dilakukan tersebut cenderung tidak mempunyai struktur institusional yang baku.

Adapun kajian dari penelitian ini ialah untuk mencapai tujuan penulisan yaitu untuk mengetahui pengaruh yang signifikan pada praktik belajar kewarganegaraan berbasis media massa terhadap keterampilan berpikir kritis siswa dan bagaimana implikasinya terhadap ketahanan pribadi siswa. Selanjutnya, berdasarkan uraian permasalahan dan beberapa hasil penelitian yang relevan, peneliti merumuskan hipotesis penelitian yaitu ada pengaruh signifikan positif model praktik belajar kewarganegaraan berbasis media massa terhadap keterampilan berpikir kritis siswa yang selanjutnya akan berimplikasi pada ketahanan pribadi siswa.

Landasan teori yang digunakan dalam penelitian ini yaitu teori tentang praktik belajar kewarganegaraan, media massa, keterampilan berpikir kritis, dan ketahanan pribadi. Dalam pelaksanaan proses pembelajaran di sekolah diperlukan sebuah model, model itu sendiri dijelaskan oleh Kolyada, Bugayeva, \& Kapranov (2016: 90) yang melakukan penelitian tentang Energizing students in class on the basis of positional training model, bahwa The position model of training removes the formal moments of educational process, communication failure between teachers and students, between training material and those who study it. Adapun praktik belajar kewarganegaraan atau project citizen merupakan suatu instructional treatment yang berbasis pada masalah untuk mengembangkan suatu pengetahuan, kecakapan, dan watak kewarganegaraan demokratis yang memungkinkan dan mendorong pada suatu keikutsertaan dalam pemerintahan dan masyarakat sipil (civil society) (Budimansyah, 2009:1). Praktik belajar kewarganegaraan menjadi sarana untuk melibatkan siswa dalam melakukan penyelidikan dalam suatu permasalahan sebagai warga negara (Pingul, 2015:61). Adapun tentang media massa, Bungin (2006:72) menjelaskan bahwa media massa merupakan sebuah medium untuk penyampaian informasi melalui sarana komunikasi. Informasi ini harus kemudian dikaji secara kritis oleh masyarakat, hak ini dikarenakan berpikir kritis pada dasarnya menuntut suatu interpretasi dan evaluasi terhadap sumber-sumber informasi sehingga akan menimbulkan jiwa yang waspada dan kritis (Fisher, 2009:13).

Selanjutnya, kajian tentang ketahanan pribadi merupakan bagian dari kajian ketahanan nasional. Ketahanan nasional itu sendiri 
merupakan kondisi dinamis yang terjadi pada perikehidupan berbangsa dan bernegara (Sunardi, 1997:5). Pada dasarnya ketahanan pribadi merupakan turunan dari ketahanan nasional, yang berawal dari tingkat nasional kemudian turun ke dalam diri pribadi setiap individu. Soedarsono (1997:53-54) menjelaskan ketahanan pribadi yang perlu ditumbuhkembangkan dan harus dapat mencerminkan sosok manusia Indonesia yang berkepribadian Pancasila dengan segala implikasinya dan menunjukkan pribadi yang memiliki watak untuk dapat diandalkan, memegang prinsip dan seseorang yang berfokus dalam menyelesaikan pekerjaan secara tuntas.

Penelitian ini merupakan kuasi eksperimen karena tidak semua variabel penelitian yang muncul dan kondisi dari eksperimen dapat diatur dan dikontrol secara ketat (full randomize), sedangkan desain dalam penelitian ini adalah dengan desain kontrol grup pretestposttest yang bertujuan untuk mengetahui keadaan objek yang diteliti sebelum dan setelah diberikan treatment (perlakuan). Pada kelompok eksperimen diberikan perlakuan dalam pembelajaran menggunakan model praktik belajar kewarganegaraan dan kelompok kontrol menggunakan model konvensional. Masing-masing kelompok kemudian diberikan pretest dan posttest. Desain penelitian ini dapat dilihat pada tabel 1.

Tabel 1

Desain Penelitian

\begin{tabular}{lllll}
\hline $\mathrm{E}$ & $(\mathrm{R})$ & $\mathrm{O}_{1}$ & $\mathrm{X}_{1}$ & $\mathrm{O}_{2}$ \\
\hline $\mathrm{K}$ & $(\mathrm{R})$ & $\mathrm{O}_{1}$ & - & $\mathrm{O}_{2}$ \\
\hline
\end{tabular}

Sumber: Diolah Peneliti,2017

Keterangan: $\mathrm{E}=$ Kelas eksperimen; $\mathrm{K}=$ Kelas kontrol; $\mathrm{R}=$ Dipilih dengan random (acak); X1= Pembelajaran Praktik Belajar Kewarganegaraan Berbasis Media Massa; $\mathrm{O} 1=$ Pretest $;$ dan $\mathrm{O} 2=$ Posttest

Di dalam penelitian ini terdapat sebuah perlakuan yaitu perlakuan berupa proses pembelajaran praktik belajar kewarganegaraan berbasis media massa. Penelitian ini dilakukan pada kelas XI semester 2 di SMA Negeri 4 Surakarta, Jawa Tengah, tahun ajaran 2017/2018. Populasi dalam penelitian ini adalah seluruh peserta didik kelas XI semester 2 di SMA Negeri 4 Surakarta Tahun Pembelajaran 2017/2018. Banyak peserta didik kelas XI keseluruhan adalah 340 siswa yang terbagi ke dalam 11 kelas yakni 7 kelas jurusan MIPA dan 4 kelas jurusan IPS. Pemilihan sampel dalam penelitian ini dilakukan dengan teknik simple random sampling karena populasi penelitian dianggap homogen, dengan cara menentukan kelas secara acak. Hal ini untuk menguatkan kesamaan atau kehomogenan kelas yang dijadikan sebagai sampel. Adapun cara penentuan sampelnya yaitu dengan objektivitas data rata-rata nilai PPKn yang diurutkan dari data rata-rata terendah sampai data rata-rata tertinggi, diperoleh data ratarata nilai yang sama antara kelas XI MIPA 2 dan XI IPS 2 yakni 62, sehingga hasil dari simple random sampling dalam penelitian ini diperoleh kelas yang dijadikan sampel penelitian yakni kelas XI MIPA 2 sebagai kelompok eksperimen, dan kelas XI IPS 2 sebagai kelompok kontrol. Pengumpulan data dilakukan dengan pretest, posttest, dan kuesioner penilaian diri keterampilan berpikir kritis siswa. Peneliti melakukan tindakan dengan memberikan perlakuan menggunakan praktik belajar kewarganegaraan berbasis media massa pada kelas eksperimen.

Teknik analisis dilakukan dengan teknik analisis statistik deskriptif. Dilakukan uji prasyarat, berupa uji normalitas dan uji homogenitas. Data yang dianalisis dalam penelitian ini adalah data hasil pretest, posttest kuesioner keterampilan berpikir kritis siswa. Uji normalitas dan uji homogenitas 
merupakan uji prasyarat sebuah data, dalam penelitian ini dilakukan dengan menggunakan software SPSS 22.0. for windows. Tahap selanjutnya yaitu dilakukan uji analisis data yang digunakan untuk menguji hipotesis dalam penelitian menggunakan Multivariate Analysis of Variance (Manova). Uji tersebut digunakan apabila hasil prasyarat analisis data menunjukkan data terdistribusi normal dan bersifat homogen. Akan tetapi, apabila hasil prasyarat analisis data menunjukkan data tidak terdistribusi normal dan tidak homogen, maka analisis data menggunakan statistik non parametric. Kedua uji tersebut menggunakan program SPSS 22.0. for windows.

Analisis data keterampilan berpikir kritis siswa dilakukan untuk mengetahui hipotesis $\mathrm{H}_{1}$ ditolak atau diterima. Analisis data untuk uji hipotesis dilakukan dengan uji univariat. Uji ini dilakukan untuk mengetahui pengaruh praktik pembelajaran kewarganegaraan terhadap variabel dependen yaitu keterampilan berpikir kritis siswa yang kemudian dilengkapi dengan analisis implikasi terhadap ketahanan pribadi siswa berdasarkan pada dasar observasi penelitian. Kriteria pengujiannya yaitu jika harga $\mathrm{F}$ pada Hotteling's Trace menghasilkan angka signifikansi lebih kecil $(<)$ dari 0,05, maka secara signifikan terdapat pengaruh positif (searah) praktik belajar kewarganegaraan berbasis media massa terhadap keterampilan berpikir kritis siswa pada pembelajaran PPKn di SMA N 4 Surakarta, Jawa Tengah.

\section{PEMBAHASAN}

Dalam pelaksanaan penelitian, proses pembelajaran praktik belajar kewarganegaraan berbasis media massa, dilakukan dengan langkah-langkah yang diawali dengan mengidentifikasi masalah sampai dengan menyusun portofolio kelas. Berikut deskripsi data temuan penelitian, dalam tabel 2 .

Tabel 2 memuat hasil data statistik deskriptif berupa mean (rata-rata), standar deviasi, minimum values (nilai minimum), dan maximum values (nilai maksimum) baik sebelum dan setelah perlakuan. Dari data terlihat bahwa mean (rata-rata) kelas eksperimen praktik belajar kewarganegaraan sebelum perlakuan adalah 43,50 dan setelah perlakuan sebesar 45,13 , dan rata-rata kelas kontrol dengan model pembelajaran konvensional sebelum perlakuan adalah 41,87 dan setelah perlakuan sebesar 44,27. Standar deviasi kelas eksperimen praktik belajar kewarganegaraan sebelum perlakuan adalah 5,322 (Lima koma tiga ratus dua puluh dua)

Tabel 2

Deskripsi Data Kuesioner Keterampilan Berpikir Kritis Siswa Sebelum (Pretest) dan Setelah (Posttest) Perlakuan

\begin{tabular}{|c|c|c|c|c|c|c|}
\hline \multirow[t]{2}{*}{ Deskripsi } & \multicolumn{2}{|c|}{$\begin{array}{c}\text { Eksperimen } \\
\text { Praktik Belajar } \\
\text { Kewarganegaraan }\end{array}$} & \multirow[t]{2}{*}{ Kesimpulan } & \multicolumn{2}{|c|}{$\begin{array}{c}\text { Kontrol } \\
\text { Konvensional }\end{array}$} & \multirow[t]{2}{*}{ Kesimpulan } \\
\hline & Sebelum & Setelah & & Sebelum & Setelah & \\
\hline Banyak Peserta Didik & 30 & 30 & Rata-rata angket & 30 & 30 & \multirow{7}{*}{$\begin{array}{l}\text { Rata-rata angket } \\
\text { keterampilan berpikir } \\
\text { kritis siswa kelas } \\
\text { kontrol sebelum dan } \\
\text { setelah perlakuan } \\
\text { mengalami peningkatan }\end{array}$} \\
\hline Rata-rata & 43,50 & 45,13 & keterampilan & 41,87 & 44,27 & \\
\hline Median & 44,00 & 44,50 & berpikir kritis siswa & 41,00 & 44,50 & \\
\hline Varians & 28,328 & 12,464 & kelas eksperimen & 18,878 & 20,478 & \\
\hline Standar Deviasi & 5,322 & 3,530 & $\begin{array}{l}\text { Sebelum dan } \\
\text { setelah perlakuan }\end{array}$ & 4,345 & 4,525 & \\
\hline Nilai Minimum & 33 & 40 & mengalami & 34 & 35 & \\
\hline Nilai Maksimum & 52 & 53 & peningkatan & 50 & 50 & \\
\hline
\end{tabular}

Sumber: Diolah Peneliti, 2018 
Tabel 3

Kategorisasi Observasi Keterampilan Berpikir Kritis Siswa Kelas Eksperimen dan Kelas Kontrol

\begin{tabular}{ccccc}
\hline \multicolumn{4}{c}{ Observasi Keterampilan Berpikir Kritis Siswa } \\
\hline Perlakuan (Treatment) & Kelas & $\begin{array}{c}\text { Skor } \\
\text { Perolehan }\end{array}$ & Skor (\%) & Kategori \\
\hline $\begin{array}{c}\text { Praktik belajar kewarganegaraan berbasis } \\
\text { media massa }\end{array}$ & $\begin{array}{c}\text { Eksperimen (XI } \\
\text { MIPA 2) }\end{array}$ & 53 & $56,4 \%$ & Aktif \\
\hline Konvensional & $\begin{array}{c}\text { Kontrol (XI IPS } \\
\text { 2) }\end{array}$ & 41 & $43,6 \%$ & Cukup Aktif \\
\hline
\end{tabular}

Sumber: Diolah Peneliti,2018

dan setelah perlakuan sebesar 3,530, (Tiga koma lima ratus tiga puluh ) dan standar deviasi kelas kontrol dengan model pembelajaran konvensional sebelum perlakuan adalah 4,345 (Empat koma tigaratus empat puluh lima) dan setelah perlakuan sebesar 4,525. Nilai minimum kelas eksperimen dengan model praktik belajar kewarganegaraan sebelum perlakuan adalah 33 dan setelah perlakuan sebesar 40, dan nilai minimum kelas kontrol dengan model pembelajaran konvensional sebelum perlakuan adalah 34 dan setelah perlakuan sebesar 35. Nilai maksimum kelas eksperimen dengan model praktik belajar kewarganegaraan sebelum perlakuan adalah 52 dan setelah perlakuan sebesar 53, dan nilai maksimum kelas kontrol dengan model pembelajaran konvensional sebelum perlakuan adalah 50 dan setelah perlakuan sebesar 50. Hal ini menunjukkan adanya peningkatan keterampilan berpikir kritis siswa sebelum perlakuan dengan setelah perlakuan pada kelas eksperimen dengan menggunakan model praktik belajar kewarganegaraan di kelas eksperimen, dan kelas kontrol dengan model pembelajaran konvensional.

Selanjutnya dilakukan analisis penilaian observasi pada saat perlakuan dalam proses penelitian. Instrumen lembar observasi keterampilan berpikir kritis siswa menggunakan skala Likert $(1-4)$ yaitu dengan
4 nilai tertinggi dan 1 nilai terendah. Skala 4 $=$ selalu, skala $3=$ sering, skala $2=$ kadangkadang, dan skala 1 = tidak pernah. Hasil observasi dihitung dengan persentase, yakni Nilai $=\frac{\text { Skor perolehan }}{\text { Skor maksimal }} X 100 \%$. Penentuan kategori persentase observasi keterampilan berpikir kritis siswa menggunakan kriteria dengan skala sebagai berikut: (1). Kurang Aktif $=$ Banyak peserta didik yang melakukan aktivitas $<25 \%$. (2). Cukup Aktif = Banyak peserta didik yang melakukan aktivitas $25 \%$ sampai dengan 50\%. (3). Aktif = Banyak peserta didik yang melakukan aktivitas 51\% sampai dengan 75\%. (4). Sangat Aktif $=$ Banyak peserta didik yang melakukan aktivitas $>75 \%$.

Berdasar tabel 3 diketahui bahwa skor hasil observasi keterampilan berpikir kritis siswa pada kelas eksperimen dengan menggunakan model praktik belajar kewarganegaraan berbasis media massa memperoleh skor persentase sebesar $56,4 \%$ dan termasuk ke dalam kategori aktif, dan hasil observasi keterampilan berpikir kritis siswa pada kelas kontrol dengan menggunakan model pembelajaran konvensional memperoleh skor persentase sebesar $43,6 \%$ dan termasuk ke dalam kategori cukup aktif. Berikut diagram kategorisasi observasi keterampilan berpikir kritis siswa kelas eksperimen dan kelas kontrol (lihat juga gambar 2). 
Gambar 2

Kategorisasi Observasi Keterampilan Berpikir Kritis Siswa

Kelas Eksperimen dan Kelas Kontrol

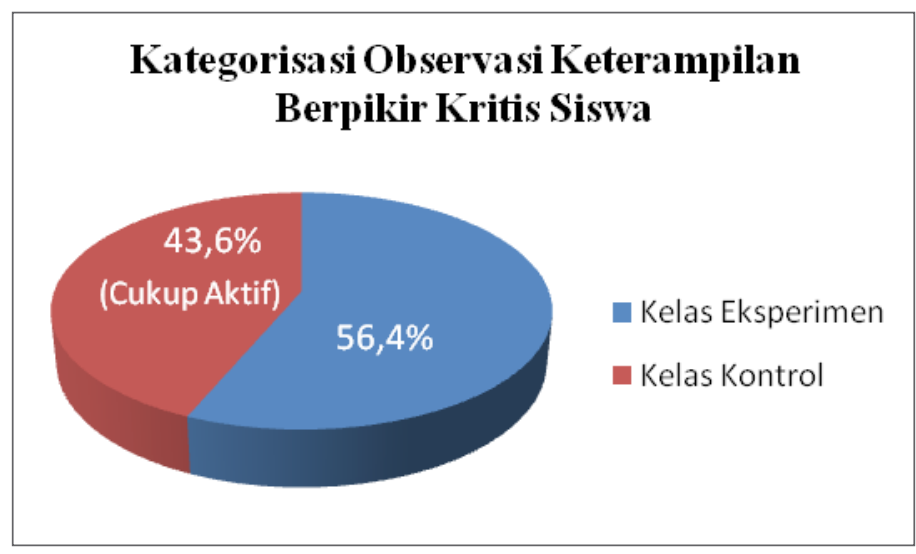

Sumber: Diolah Peneliti,2018

Selanjutnya, dilakukan analisis data uji prasyarat. Data yang diperoleh sebelum dan setelah perlakuan meliputi data hasil tes dan angket yakni data keterampilan berpikir kritis siswa untuk kelas eksperimen dan kelas kontrol. Analisis uji prasyarat dilakukan dengan uji normalitas dan uji homogenitas. Uji normalitas dilakukan untuk mengetahui apakah data-data berdistribusi normal atau tidak normal pada data kelas eksperimen dan kelas kontrol. Penelitian ini menggunakan metode Kolmogorov-Smirnov untuk pengujian normalitas dengan bantuan software SPSS 22.0. for windows. Kriteria pengujian berasal dari populasi data yang terdistribusi normal jika nilai signifikansinya lebih besar dari 0,05.

Berdasar tabel 4 diketahui bahwa data uji normalitas sebelum dan setelah perlakuan diperoleh nilai signifikansi lebih dari 0,05 . Hal ini menunjukkan bahwa data berdistribusi normal. Jadi, data ini telah memenuhi syarat untuk dianalisis. Tahap selanjutnya setelah uji normalitas adalah uji homogenitas varians. Selanjutnya, uji homogenitas dimaksudkan untuk mengetahui data yang dianalisis homogen atau tidak homogen. Kriteria pengujian berasal dari populasi data yang homogen jika nilai signifikansinya lebih besar dari 0,05. Pengujian homogenitas untuk uji multivariat menggunakan uji Box's Mtest jika tidak ada perbedaan atau kedua varians-kovarians sama. Berikut hasil analisis uji homogenitas yang dilakukan dengan bantuan program SPSS 22.0. for windows.

Tabel 4

Ringkasan Hasil Uji Coba Normalitas Sebelum dan Setelah Perlakuan (Kolmogorov Smirnov)

\begin{tabular}{lcc}
\hline \multirow{2}{*}{ Variabel } & Nilai Signifikansi & \multirow{2}{*}{ Keterangan } \\
\cline { 2 - 3 } & Keterampilan Berpikir Kritis & Distribusi Normal \\
Pretest eksperimen & $0,200^{*}$ & Distribusi Normal \\
Posttest eksperimen & $0,200^{*}$ & Distribusi Normal \\
Pretest kontrol & $0,200^{*}$ & Distribusi Normal \\
Posttest kontrol & 0,119 & \\
\hline
\end{tabular}

Sumber: Diolah Peneliti,2018 
Dian Eka Putri -- Pengaruh Praktik Belajar Kewarganegaraan Berbasis Media Massa Terhadap Keterampilan Berpikir Kritis dan Implikasinya Terhadap Ketahanan Pribadi Siswa

Tabel 5

Ringkasan Hasil Uji Homogenitas Data Sebelum dan Setelah Perlakuan (Box's $M$ )

\begin{tabular}{ccccccc}
\hline Variabel & Box's $M$ & F hitung & df 1 & df 2 & Sig. & Keterangan \\
\hline Sebelum & 2,891 & 0,928 & 3 & 605520,000 & 0,426 & Homogen \\
\hline Setelah & 5,017 & 1,610 & 3 & 605520,000 & 0,185 & Homogen \\
\hline
\end{tabular}

Sumber: Diolah Peneliti,2018

Tabel 6

Hasil Uji Univariat Praktik Belajar Kewarganegaraan dan Keterampilan Berpikir Kritis Siswa

\begin{tabular}{ccccccc}
\hline \multicolumn{2}{c}{ Source } & Df & Mean Square & F & Sig. & Kesimpulan \\
\hline $\begin{array}{c}\text { Praktik Belajar } \\
\text { Kewarganegaraan }\end{array}$ & $\begin{array}{l}\text { Keterampilan } \\
\text { Berpikir Kritis }\end{array}$ & 1 & 91,267 & 4,787 & 0,033 & Berpengaruh \\
\hline
\end{tabular}

Sumber: Diolah Peneliti,2018

Berdasar tabel 5 dapat diketahui bahwa besarnya nilai Box's $M$ sebelum perlakuan adalah 2,891 dengan nilai $F_{\text {hitung }}$ sebesar 0,928 , sedangkan tingkat signifikansinya adalah 0,426 yang berarti lebih besar dari 0,05 . Hal ini menunjukkan matriks varianskovarians pada variabel dependen adalah homogen. Nilai Box's $M$ setelah perlakuan adalah 5,017 dengan nilai $F_{\text {hitung }}$ sebesar 1,610, sedangkan tingkat signifikansinya adalah 0,185 yang berarti lebih besar dari 0,05 . Berdasarkan data setelah perlakuan, hasil perhitungan menggunakan SPSS 22 for windows menunjukkan matriks varianskovarians pada variabel dependen adalah homogen. Jadi, data tersebut telah memenuhi syarat untuk dianalisis.

Adapun langkah selanjutnya yaitu dilakukan uji hipotesis dengan uji univariat tentang perbedaan keefektivan antara penggunaan praktik belajar kewarganegaraan berbasis media massa pada kelas eksperimen, dan model pembelajaran konvensional pada kelas control. Uji hipotesis dilakukan dengan analisis uji univariat untuk melihat pengaruh signifikan antara model praktik belajar kewarganegaraan berbasis media massa terhadap keterampilan berpikir kritis siswa dibandingkan dengan model pembelajaran konvensional. Kaidah keputusan yang digunakan apabila nilai sig. $\leq 0,05$, maka $\mathrm{H}_{1}$ diterima.

Berdasar tabel 6 diketahui bahwa nilai $F$ adalah 4,787 dengan nilai signifikansi sebesar 0,033 lebih kecil dari 0,05. Hal ini berarti bahwa terdapat pengaruh signifikan model praktik belajar kewarganegaraan berbasis media massa terhadap keterampilan berpikir kritis siswa. Kemudian pada tabel 6 menunjukkan angka koefisien signifikansi sebesar 0,033 bertanda positif menunjukkan arah positif (searah), mengandung pengertian bahwa semakin tinggi skor variabel pertama maka semakin tinggi pula skor variabel kedua. Artinya bahwa semakin baik penerapan model pembelajaran praktik belajar kewarganegaraan berbasis media massa pada pembelajaran PPKn maka semakin baik pula keterampilan berpikir kritis siswa. Dengan demikian, dapat disimpulkan bahwa $\mathrm{H}_{1}$ diterima yang berarti terdapat pengaruh signifikan positif pembelajaran praktik belajar kewarganegaraan berbasis media massa terhadap keterampilan berpikir kritis siswa.

Selanjutnya, hasil analisis data menunjukkan adanya pengaruh signifikan positif dari pengguanaan model praktik belajar kewarganegaraan berbasis media massa 
terhadap keterampilan berpikir kritis siswa dalam pembelajaran PPKn di SMA Negeri 4 Surakarta. Hal ini diperoleh dengan melakukan analisis univariat untuk mengetahui ada atau tidaknya pengaruh model praktik belajar kewarganegaraan berbasis media massa terhadap keterampilan berpikir kritis siswa. Kaidah keputusan yang digunakan adalah apabila nilai sig. $\leq 0,05$, maka $\mathrm{H}_{1}$ diterima yang berarti bahwa ada pengaruh signifikan positif antara model pembelajaran praktik belajar kewarganegaraan berbasis media massa terhadap keterampilan berpikir kritis siswa pada pembelajaran PPKn dibandingkan dengan model pembelajaran konvensional. Adapun hasil uji univariat, diperoleh $\mathrm{F}$ sebesar 4,787 dan nilai sig. $\leq 0,05$ yaitu 0,033, sehingga dapat disimpulkan bahwa $\mathrm{H}_{1}$ diterima yang membuktikan adanya pengaruh signifikan positif model pembelajaran praktik belajar kewarganegaraan berbasis media massa terhadap keterampilan berpikir kritis siswa pada pembelajaran PPKn.

Hasil penelitian yang menunjukkan adanya pengaruh signifikan positif memperkuat temuan penelitian yang dilakukan oleh Atabaki, Keshtiaray, dan Yarmohammadian (2015:93) tentang Scrutiny of Critical Thinking Concept yang menjelaskan bahwa pada dasarnya, mempelajari keterampilan berpikir kritis adalah salah satu tujuan dari sistem pendidikan. Istilah critical thinking merupakan istilah yang berkaitan dengan dunia pendidikan, yang merepresentasikan tentang kecakapan berpikir manusia. Hasil penelitian ini mendukung teori tentang critical thinking yang dijelaskan Atabaki, dkk tersebut, bahwa keterampilan berpikir kritis dapat dibentuk melalui proses pembelajaran dalam dunia pendidikan.

Hasil temuan penelitian yang menyatakan adanya pengaruh signifikan positif penggunaan model praktik belajar kewarganegaraan berbasis media massa terhadap keterampilan berpikir kritis siswa, memperkuat hasil penelitian sebelumnya yang dilakukan oleh Jayadiputra (2015:11) tentang model praktik belajar kewarganegaraan dalam meningkatkan keterampilan berpikir kritis siswa, yang menegaskan ada perbedaan signifikan antara keterampilan kewarganegaraan siswa pada kelas yang menggunakan praktik belajar kewarganegaraan dengan yang tidak menggunakan project citizen, tingkat berpikir kritis dan konsep demokrasi siswa mencapai 84,5\%. Penelitian Jayadiputra (2015:18) ini yang menegaskan bahwa project citizen pada pembelajaran PPKn terbukti dapat meningkatkan keterampilan berpikir kritis peserta didik.

Hasil penelitian yang menegaskan adanya pengaruh signifikan model praktik belajar kewarganegaraan berbasis media massa terhadap keterampilan berpikir kritis siswa juga memperkuat hasil penelitian yang dilakukan oleh Nusarastriya, Sapriya, Wahab, dan Budimansyah (2013:448) yang mengkaji tentang pengembangan berpikir kritis dalam pembelajaran Pendidikan Kewarganegaraan menggunakan project citizen. Hasil penelitian tersebut menegaskah bahwa secara umum dalam kaitannya dengan pengembangan berpikir kritis melalui praktik belajar kewarganegaraan lebih membawa hasil yang baik dibandingkan dengan pembelajaran konvensional karena adanya proses pembelajaran demokratis dan kooperatif pada praktik belajar kewarganegaraan yang memberi suasana terbuka dan partisipatif. Secara khusus, praktik belajar kewarganegaraan memberikan stimulus pada proses pengembangan karakteristik berpikir kritis terutama pada analisis klam rasional dan emosional yang berdasarkan pada analisis data. 
Adanya pengaruh yang signifikan positif dalam penelitian ini, juga memperkuat temuan hasil penelitian yang dilakukan oleh Luqman (2017:58) yang melakukan penelitian tentang penerapan model pembelajaran project citizen untuk meningkatkan keterampilan berpikir kritis dan kreatif siswa, yang menegaskan bahwa setelah melalui tindakan siklus I dan II, maka benang merah dari penelitian ini adalah: (1) Setelah pelaksanaan pembelajaran PKn pada materi pokok keputusan bersama dapat ditunjukkan bahwa penerapan model pembelajaran project citizen dengan kelompok kecil (4-6 siswa), melalui kegiatan pendahuluan yang optimal, adanya bimbingan guru yang intensif, serta adanya motivasi ektrinsik berupa hadiah dapat meningkatkan keterampilan berpikir kritis dan kreatif pada siswa; (2). Melalui langkah-langkah model pembelajaran project citizen tersebut, dapat meningkatkan keterampilan berpikir kritis siswa. Hal tersebut terlihat dengan adanya peningkatan nilai rata-rata butir soal yang mencerminkan keterampilan berpikir kritis yaitu 9,60; dan (3). Langkah-langkah model pembelajaran project citizen yang terdiri dari 6 (enam) langkah, juga dapat meningkatkan keterampilan berpikir kreatif. Hal tersebut terlihat dengan adanya peningkatan rata-rata butir soal yang mencerminkan keterampilan berpikir kreatif yaitu 4,80.

Adanya pengaruh signifikan positif dalam penelitian ini, sesuai dengan tujuan model pembelajaran praktik belajar kewarganegaraan yang dijelaskan oleh Vontz, Metcalf, dan Patrick (2000:16) bahwa pada prinsipnya, tujuan project citizen (praktik belajar kewarganegaraan) adalah untuk mendidik tanggung jawab warga negaradan juga menerima hak kewarganegaraan demokratis Hal ini menegaskan bahwa proses dalam model pembelajaran praktik belajar kewarganegaraan mengarah pada suatu pembentukan warga negara yang kritis.

Liou (2004:81) yang mengkaji tentang The Effect of We The People...Project Citizen on the Civic Skills and Disposition of Taiwanese Senior High School Student juga memperkuat hasil penelitian dalam penelitian ini, bahwa dalam proses praktik belajar kewarganegaraan terdapat serangkaian proses partisipasi, kemampuan siswa dalam suatu kelompok, ketertarikan politik, dan komitmen pada hakhak dan tanggung jawab kewarganegaraan. Faktor yang secara signifikan menjadi efek dari project citizen pada civic skills (keterampilan kewarganegaraan) dan karakter siswa adalah iklim kelas dan informasi dari berbagai sumber, yang menunjukkan ada respon yang positif dari guru dan siswa dalam analisis sumber dan pelaksanaan pembelajaran project citizen. Dengan adanya analisis sumber, siswa lebih aktif dan terampil dalam proses berpikir dan penyelesaian masalah. Hal ini sesuai dengan kajian penelitian praktik belajar kewarganegaraan kaitannya dengan keterampilan berpikir kritis siswa, yang berdasarkan analisis data, berpengaruh signifikan secara positif.

Terkait dengan kajian model praktik belajar kewarganegaraan berbasis media massa, memperkuat hasil penelitian dengan tema kajian media massa yang dilakukan oleh Ferry (2014:42) yang mengkaji tentang peran media massa dan pengaruhnya bagi remaja, memaparkan bahwa terdapat peran media massa yang semakin masif dalam proses penyampaian informasi. Hal tersebut mengindikasikan bahwa media massa memiliki peranan penting dalam penyampaian informasi di era saat ini. Hal ini menunjukkan bahwa media massa memiliki 
potensi yang positif jika dimanfaatkan untuk pembelajaran. Adapun penelitian ini menegaskan bahwa adanya pemanfaatan media massa mengarahkan siswa untuk lebih termotivasi dalam belajar, melakukan analisis, dan menjadi tertarik dengan berbagai macam sumber informasi yang dapat dikaji dalam sebuah proses pembelajaran. Proses tersebut mengarah pada pemenuhan kompetensi siswa dalam pembelajaran PPKn berupa kompetensi pengetahuan kewarganegaraan, sikap kewarganegaraan, dan keterampilan kewarganegaraan. Di dalam komponen tersebut, keterampilan berpikir kritis masuk ke dalam komponen keterampilan kewarganegaraan (civic skills).

Adapun pada prinsipnya, hasil penelitian juga mendukung teori tentang tujuan dari model pembelajaran praktik belajar kewarganegaraan yang dijelaskan oleh Budimansyah (2009:17) yang menjelaskan bahwa pada dasarnya tujuan praktik belajar kewarganegaraan adalah untuk membentuk dan menghasilkan pengetahuan, kecakapan, watak, yang sangat dibutuhkan untuk ikut ambil dalam kehidupan berwarga negara. Para siswa diberikan motivasi untuk memberdayakan diri dalam melaksanakan tugas dan tanggung jawab sebagai masyarakat. Dengan studi intensif, siswa diarahkan untuk berpikir secara kritis dan mendalam tentang isu, fenomena, masalah, dan kebijakan yang dikaji yang kemudian diarahkan untuk membentuk seorang warga negara yang cerdas dan baik (smart and good citizen).

Berdasarkan hasil observasi, adanya pengaruh signifikan positif praktik belajar kewarganegaraan berbasis media massa terhadap keterampilan berpikir kritis, berimplikasi terhadap ketahanan pribadi siswa. Seperti yang telah dijelaskan terdahulu, bahwa ketahanan pribadi merupakan bagian dari kajian ketahanan nasional. Pada dasarnya ketahanan pribadi merupakan turunan dari ketahanan nasional, yang berawal dari tingkat nasional kemudian turun ke dalam diri pribadi setiap individu. Soedarsono (1997:5354) menjelaskan ketahanan pribadi yang perlu ditumbuh-kembangkan harus dapat mencerminkan sosok manusia Indonesia yang berkepribadian Pancasila dengan segala implikasinya dan menunjukkan pribadi yang memiliki watak untuk dapat diandalkan, memegang prinsip dan seseorang yang berfokus dalam menyelesaikan pekerjaan secara tuntas. Berdasarkan data observasi dapat ditunjukkan bahwa dalam proses pembelajaran praktik belajar kewarganegaraan berbasis media massa, siswa terlihat lebih kritis dalam rangka menganalisis sumbersumber belajar yang diambil dari media massa. Dalam prosesnya, siswa menganalisis lebih jauh tentang berbagai macam isi berita dari media massa, merumuskan indikator tentang isi berita, ada atau tidaknya kepentingan dalam judul dan pembahasan isi berita, berdiskusi utuk menyimpulkan sikap yang diambil dalam menanggapi isi setiap berita yang bersumber dari media massa. Proses ini menegaskan adanya kondisi dinamis pada siswa yang memiliki pola pikir kritis dalam menanggapi segala macam isi berita. Artinya, siswa semakin cerdas dalam menanggapi isi berita, hal ini dapat menghindari adanya kekhawatiran bahwa berita hoax akan mengancam kelangsungan kehidupan berbangsa dan bernegara, karena siswa memiliki ketahanan pribadi untuk berpikir kritis dalam menanggapi segala informasi yang ditemuinya dalam media massa.

Hasil temuan data observasi tersebut memperkuat hasil penelitian Widayanti, Armawi dan Andayani (2018) bahwa 
pendidikan wawasan kebangsaan akan membentuk perilaku siswa yang bertanggung jawab atas segala tindakan dan perbuatannya sehingga memiliki karakter kebangsaan hingga tercapainya ketahanan pribadi siswa. Pendidikan wawasan kebangsaan ini juga merupakan bagian dari proses pembelajaran PPKn dimana dalam penelitian ini, penerapan praktik belajar kewarganegaraan berbasis media massa dilakukan dalam proses pembelajaran PPKn di Kelas XI. Adapun terkait dengan implikasi penelitian terhadap ketahanan pribadi siswa, menguatkan hasil penelitian yang dilakukan oleh Wahana (2015) tentang kajian nilai-nilai budaya dan ketahanan individu, bahwa nilai-nilai budaya perlu terus diperjuangkan karena hasil penelitian menunjukkan bahwa pengaruh nilai-nilai budaya ini berdampak kuat terhadap pembentukkan ketahanan individu. Adanya korelasi yang signifikan ini kemudian mengaskan bahwa perlu adanya penguatan nilai-nilai budaya generasi milennial melalui pemanfaatan perkembangan dari budaya milennial itu sendiri yaitu perkembangan teknologi informasi dan komunikasi. Dalam penelitian ini dilakukan suatu pemanfaatan media massa dari berbagai jenis media massa baik media lama (cetak) maupun media baru (online/internet). Adanya pemanfaatan media massa baik cetak maupun online dalam proses pembelajaran di sekolah, merupakan suatu bentuk pemanfaatan positif terhadap hal-hal yang berkembang pada generasi milennial.

Pada akhirnya, hasil penelitian mengenai adanya pengaruh signifikan model praktik belajar kewarganegaraan berbasis media massa terhadap keterampilan berpikir kritis siswa dan implikasinya terhadap ketahanan pribadi siswa, menegaskan bahwa pada dasarnya penerapan praktik belajar kewarganegaraan mengarahkan siswa untuk berpikir secara logis dengan analisis argumen dan penemuan solusi permasalahan, yang kemudian dijadikan sebagai pengalaman belajar dan menjadi pengetahuan kewarganegaraan siswa untuk meningkatkan keterampilan berpikir kritis siswa dan ketahanan pribadi siswa.

\section{SIMPULAN}

Berdasarkan penjabaran data yang telah dianalisis dan dibahas, maka dapat ditarik simpulan sebagai berikut.

Pertama, hasil penelitian menunjukkan adanya pengaruh signifikan positif praktik belajar kewarganegaraan berbasis media massa terhadap keterampilan berpikir kritis siswa pada pembelajaran PPKn di SMA Negeri 4 Surakarta Jawa Tengah. Hal ini ditunjukkan dengan nilai F sebesar 4,787 dan sig. $\leq 0,05$ yaitu 0,033 . Angka 0,033 bertanda positif menunjukkan arah positif (searah), artinya bahwa semakin baik penerapan praktik belajar kewarganegaraan berbasis media massa maka semakin baik pula keterampilan berpikir kritis siswa.

Kedua, keterampilan berpikir kritis yang menunjukkan arah positif (searah) berimplikasi terhadap ketahanan pribadi siswa sesuai dengan data hasil observasi lapangan yang menunjukkan indikatorindikator ketahanan pribadi siswa, terutama dalam proses pemikiran kritis yang dilakukan oleh siswa berupa penyampaian pendapat yang berdasarkan data dan fakta, tidak mudah percaya akan informasi yang diterima dari media massa, dan sikap kritis terhadap suatu pemberitaan yang diterima melalui media massa.

Ketiga, keterampilan berpikir kritis yang dimiliki siswa pada dasarnya merupakan pemikiran secara jelas atau logis 
dan benar-benar melihat secara mendalam terhadap berbagai konsep yang relevan dengan mengeksplorasi hal-hal seperti masalah yang mendasar. Dalam proses berpikir kritis, semua hal dipertimbangkan untuk direnungkan, dipikirkan, kemudian disimpulkan secara logis dan jelas. Hal ini merupakan keterampilan berpikir tingkat tinggi yang menjadi ketahanan pribadi siswa sebagai warga negara muda dalam rangka analisis penyelesaian masalah.

\section{DAFTAR PUSTAKA}

Asosiasi Penyelenggara Jasa Internet Indonesia (APJII), 2017, Penetrasi \& Perilaku Pengguna Internet Indonesia, Jakarta: Teknopreuner Indonesia.

Atabaki, A, M, S, Keshtiaray, N \& Yarmohammadian, M,H, 2015, 'Scrutiny of critical thinking concept', International Education Studies, vol. 8, no. 3, hh. 93102.

Budimansyah, Dasim, 2009, Inovasi pembelajaran project citizen, Bandung: Program Studi Pendidikan Kewarganegaraan, Sekolah Pascasarjana UPI.

Bungin, Burhan, 2006, Sosiologi komunikasi teori, paradigma, dan diskursus teknologi komunikasi di masyarakat, Jakarta: Kencana Prenadamedia Group.

Cogan, J.J \& Derricott, R, 1998, Citizenship for the 21st century: an international perspective on education, London: Kogan Page Limited.

Fajar, Arnie, 2005, Portofolio dalam pembelajaran IPS, Bandung: PT. Remaja Rosdakarya.

Ferry, R.P.P.S, 2014, 'Kajian peran media massa dan pengaruhnya bagi remaja',
Jurnal Pengembangan Humaniora, vol. 14, no. 1, hh. 33-44.

Fisher, Alec, 2009, Berpikir kritis sebuah pengantar, Jakarta: Penerbit Erlangga.

Hamidi, Jazim \& Lutfi, Mustafa, 2010, Civic education antara realitas politik dan implementasi hukumnya, Jakarta: PT Gramedia Pustaka Utama.

Jayadiputra, Eka, 2015, 'Model project citizen dalam meningkatkan keterampilan berpikir kritis siswa', Jurnal Ilmiah Cisoc: Kajian Kampus Pendidikan Ilmu Sosial, vol. 2, no. 1, hh. 11-20. http://jurnal.fkip-uninus. ac.id/index.php/cisoc/index.

Kaelan, 2012, 'Membangun karakter guru menjadi smart and good citizen', Jurnal PKn Progresif, vol. 7, no. 1, hh. 63-84.

Kerr, David, 1999, Citizenship education: an international comparison, London: Quality Curriculum Association.

Kolyada, M., Bugayeva, T., \& Kapranov, G. (2016). Energizing students in class on the basis of positional training model. The New Educational Review, 43(1), 78-91. DOI: 10.15804/tner.2016.43.1.06

Liou, Show-Mann, 2004, 'The effect of we the people...project citizen on the civic skills and dispositions of Taiwanase senior high school student', Journal of Taiwan Normal University: Education, vol. 49, no. 1, hh. 63-90. http://jories.ntnu.edu.tw/jres/.

Luqman, 2017, 'Penerapan model pembelajaran project citizen untuk meningkatkan keterampilan berpikir kritis dan kreatif siswa', Jurnal Ilmu Pendidikan, vol. 2, no. 1, hh. 44-59.

Nusarastriya, Y.H, Sapriya, H, Wahab, A.A \& Budimansyah, Dasim, 2013, 'Pengembangan berpikir kritis dalam 
pembelajaran pendidikan kewarganegaraan menggunakan project citizen', Cakrawala Pendidikan, vol. 32, no. 3, hh. 444-449. https://journal.uny.ac.id/ index.php/cp/ index.

Pingul, F.S, 2015, 'Measuring the impact of a supplemental civic education program on students' civic attitude and efficacy beliefs', Journal of Education and Training Studies, vol. 3, no. 2, hh. 61-69. http:// dx.doi.org/10.11114/jets.v3i2.600.

Raharjo, Armawi, Armaidy \& Soerjo, Djoko, 2017, 'Penguatan Civic Literacy Dalam Pembentukan Warga Negara Yang Baik (Good Citizen) Dan Implikasinya Terhadap Ketahanan Pribadi Warga Negara Muda (Studi Tentang Peran Pemuda HMP PPKn Demokratia Pada Dusun Binaan Mutiara Ilmu Di Jebres, Surakarta, Jawa Tengah)', Jurnal Ketahanan Nasional, vol. 23, no. 2, Agustus 2017, hh.175-198.

Soedarsono, S, 1997, Ketahanan Pribadi dan Ketahanan Keluarga Sebagai Tumpuan Ketahanan Nasional, Jakarta: PT Intermasa.

Sunardi, 1997, Teori Ketahanan Nasional, Jakarta: Hastannas.

Suwignyo, Agus \& Yuliantri, Rhoma Dwi Aria, 2018, 'Praktik Kewargaan Seharihari Sebagai Ketahanan Sosial Masyarakat Tahun 1950-an (Sebuah Tinjauan Sejarah)', Jurnal Ketahanan Nasional, vol. 24, no.1, April 2018, hh. 94-116.

Vontz, T.S, Metcalf, K.K \& Patrick, J.J, 2000, "Project Citizen" and the civic development of adolescent students in Indiana, Latvia, and Lithuania, Bloomington IN: ERIC Clearinghouse for Social Studies/Social Science Education.

Wahab, A.A \& Sapriya, 2008, Teori dan landasan pendidikan kewarganegaraan, Bandung: UPI Press Sekolah Pascasarjana Universitas Pendidikan Indonesia.

Wahana, Heru Dwi, 2015, 'Pengaruh NilaiNilai Budaya Generasi Millennial Dan Budaya Sekolah Terhadap Ketahanan Individu (Studi Di SMA Negeri 39, Cijantung, Jakarta)', Jurnal Ketahanan Nasional, Nomor XXI, Volume 1, April 2015, hh. 14-22.

Widayanti, Windy Kartika Putri, Armawi, Armaidy \& Andayani, Budi, 2018, 'Wawasan Kebangsaan Siswa Sekolah Menengah Atas Dan Implikasinya Terhadap Ketahanan Pribadi Siswa (Studi Pada Siswa Sekolah Menengah Atas (SMA) Umum Berasrama Berwawasan Nusantara, SMA Umum Di Lingkungan Militer Dan SMA Umum Di Luar Lingkungan Militer Di Kabupaten Magelang, Provinsi Jawa Tengah)', Jurnal Ketahanan Nasional, vol. 24, no.1, April 2018, hh. 1-26.

Winataputra, Udin \& Budimansyah, Dasim, 2012, Pendidikan kewarganegaraan dalam perspektif internasional (konteks, teori, dan profil pembelajaran), Bandung: Widya Aksara Press.

\section{Peraturan Perundangan}

Undang-Undang Republik Indonesia Nomor 20 Tahun 2003 tentang Sistem Pendidikan Nasional. 